\title{
SISTEM PAKAR PENERAPAN METODE CASE BASED REASONING UNTUK IDENTIFIKASI PENYAKIT CABAI BERBASIS WEB
}

\author{
Rynaldi Maldini \\ Program Studi Teknik Informatika S1, Fakultas Teknologi Industri \\ Institut Teknologi Nasional Malang, Jalan Raya Karanglo km 2 Malang, Indonesia \\ renaldimaldini846@gmail.com
}

\begin{abstract}
ABSTRAK
Penyebab utama masih rendahnya jumlah produksi tanaman cabai adalah sering terserang hama dan penyakit yang menyebabkan pertumbuhan tanaman menjadi tidak optimal banyaknya jenis penyakit yang dapat menyerang tanaman cabai serta sulitnya proses deteksi karena adanya kemiripan gejala yang ditimbulkan membuat para petani cabai tidak bisa menentukan langkah pencegahan dan pengendalian yang tepat salah satu usaha yang di lakukan dengan membangun sistem pakar penerapan metode case based reasoning untuk identifikasi penyakit cabai.

Sistem pakar penerapan metode case based reasoning untuk identifikasi penyakit cabai merupakan sistem yang dirancang dengan menggunakan bahasa pemrograman yang digunakan adalah bahasa pemrograman php dan html dimana akan di hasilkan suatu sistem yang bermanfaat bagi masyarakat umum, Khususnya BPTP (balai pengkajian teknologi pertanian) dalam mendapatkan informasi tentang penyakit cabai dan gejala.

Hasil pengujian dari sistem yang telah dibangun yaitu sistem pakar penerapan metode case based reasoning untuk identifikasi penyakit cabai berbasis web menyatakan bahwa hasil dari program yang telah dibuat memiliki hasil yang cukup sesuai, itu di buktikan dengan hasil pengujian terhadap cara kerja program dengan menggunakan simililarity yang terdapat 5 kasus yaitu Ani, Umar, Nawi, Doel dan swastika masing masing memiliki persamaan yang berbeda. didapatkan nilai kesamaan yang terbesar yaitu kasus dengan Ani sebanyak 0,75 dan disusul oleh Umar dan swastika dengan nilai 0,15 serta yang terakhir Nawi dan Doel dengan perolehan similiarity sama dengan 0 dan pengujian fungsional sistem dengan akses sebagai admin, user sesuai dengan fungsinya pada browser. Pada tahap pengujian aplikasi dengan menggunakan 3 browser yaitu Mozilla Firefox, Google Crome dan Microsoft Edge Semua fungsi dari sistem berjalan sesuai dengan yang di inginkan.
\end{abstract}

Kata Kunci : Penyakit Cabai, Sistem pakar, Case Based Reasoning

\section{PENDAHULUAN}

Tanaman cabai merupakan tanaman yang sangat banyak dibudidayakan oleh para petani di seluruh tanah air. Budidaya mulai dari sistem intensif (modern) dan sistem ektensif (sistem tradisional). Umumnya petani menggunakan sistem intensif guna meningkatkan produktifitas dan peningkatan hasil panen (Nurfalach,2010). Dalam meningkatkan produksi panen petani menggunakan sistem pemupukan, perawatan, prospek budidaya tanaman cabai telah menjadi usaha yang menjanjikan bagi petani. Pada saat musim hujan, produksi cabai berkurang, sementara permintaan konstan dan kontinu setiap hari, bahkan meningkat pada musim tertentu. Salah satu penyebab produksi menurun adalah penyakit tanaman cabai.

Penyebab utama masih rendahnya jumlah produksi tanaman cabai adalah sering terserang hama dan penyakit yang menyebabkan pertumbuhan tanaman menjadi tidak optimal. Banyaknya jenis penyakit yang dapat menyerang tanaman cabai serta sulitnya proses deteksi karena adanya kemiripan gejala yang ditimbulkan membuat para petani cabai tidak bisa menentukan langkah pencegahan dan pengendalian yang tepat untuk mengatasi penyakit tersebut. hama dan penyakit merupakan kendala yang sering dihadapi para petani serta pengambilan keputusan pada proeses penanggulangan menyebabkan terjadinya kegagalan panen, terutama pada tanaman cabai. Sebagian besar kegagalan panen disebabkan karena tanaman diserang oleh hama dan penyakit mikro organisme (virus, bakteri, protozoa, jamur, cacing nematode). Kadang-kadang petani tahu kalau tanamannya diserang hama/penyakit, tetapi petani tidak tahu hama/penyakit apa yang sedang menyerang tanamannya.

Berdasarkan fakta diatas, penulis merasa perlu dibuatnya sistem pakar yang bisa membantu petani dalam mendiagnosis penyakit pada tanaman cabai serta memberikan solusi pertolongan pertama yang harus dilakukan. Sistem ini akan memberikan diagnosa berdasarkan gejala-gejala yang dimasukan user 
ke dalam sistem. Sistem pakar diagnosa penyakit cabai ini akan menggunakan Metode Case Based Reasoning. Metode Case Based Reasoning akan mengambil solusi dari kasus-kasus sebelumnya untuk menyelesaikan masalah selanjutnya memberikan bobot kepada gejala-gejala yang ada berdasarkan kasus yang sebelumnya. Sistem pakar ini diharapkan dapat meneliti tentang penyakit tanaman cabai dengan menggunakan metode case based reasoning. Sistem pakar ini juga diharapkan bisa untuk membantu orang awam dalam mendiagnosa awal penyakit cabai yang sering terjadi serta dapat memberikan solusi awal dalam penanganan penyakit tersebut, sehingga dapat menyelamatkan tanaman cabai dari hama penyakit

Berdasarkan pemaparan di atas skripsi dengan judul "Sistem Pakar Penerapan Metode Case Based Reasoning Untuk Identifikasi Penyakit Cabai Berbasis Web "Dengan adanya website ini diharapkan mempermudah petani untuk mengetahui gejala mendapatkan informasi pengendalian hama / penyakit.

\section{TINJAUN PUSTAKA}

\subsection{Penelitihan Terkait}

Faktor yang mempengaruhi tingkat kepuasan penyewa pada suatu mall adalah kecepatan dan ketetapan pelayanan yang di berikan oleh manajemen mall dalam menangani complain.selama ini di Maspion square mall pihak manajemen hanya mengandalkan pada beberapa orang saja yang dianggap mampu menangani complain penyewa.oleh karena itu masing masing personil khusunya dalam hal menentukan solusi dari kasus yang ada, dimana masih terdapat kasus yang tertimbun begitu saja dan belum di kelola secara baik dalam menyelesaikan kasus kasus yang serupa. Salah satu alternative untuk membantu manajemen mall dalam memecahakan masalah penaganan complain penyewa adalah dengan sistem pendukung keputusan.salah satu sub sistem model base dari spk adalah case based reasoning(CBR)melakuhkan pencocokan terhadap kesamaan dari kasus yang ada dengan kasus sebelumnya sehingga dapat dijadikan dasar dalam pemngambilan sebuah keputusan. Dari dasil penelitian Case Based Reasioning diharapkan dapat membantu pihak manajemen mall khususnya dalam hal ketetapan penangan complain sehingga berdampak pada peningkatan kepuasan (Kartikasari, dkk:2016)

\subsection{Pengertian Sistem Pakar}

Sistem pakar adalah system perangkat lunak computer yang menggunakan ilmu, fakta, dan Teknik berpikir dalam pengambilan keputusan untuk menyelesaikan masalah-masalah yang biasanya hanya dapat diselesaikan oleh tenaga ahli dalam bidang yang bersangkutan. Seseorang yang bukan pakar menggunakan sistem pakar untuk meningkatkan kemampuan pemecahan masalah. Sistem pakar adalah suatu program yang dibuat berdasarkan suatu set aturan yang menganalisis informasi (biasanya diberikan oleh pengguna suatu sistem) mengenai suatu kelas masalah spesifik serta analisis matematis dari masalah tersebut (Sari, dkk.2012).

\subsection{Metode Case Based Reasoning (CBR)}

Case-Based Reasoning adalah metode untuk menyelesaikan masalah dengan mengingat kejadian-kejadian yang sama/sejenis (similar) yang pernah terjadi di masa lalu kemudian menggunakan pengetahuan/informasi tersebut untuk menyelesaikan masalah yang baru, atau dengan kata lain menyelesaikan masalah dengan mengadaptasi solusi-solusi yang pernah digunakan di masa lalu. Ilustrasi dari proses mendapatkan solusi case based reasoning dapat dilihat pada gambar 2.1 berikut : ( Ungkawa,dkk: 2013 )

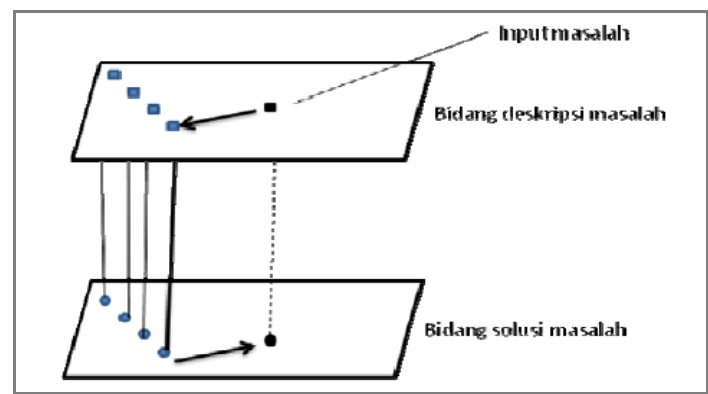

Gambar 1 Pencocokan Kasus Pada CBR

\subsection{Tahapan Dalam Metode Case Based} Reasoning

Dalam Case-Based Reasoning ada empat tahapan yang meliputi:

\section{Retrieve}

Mendapatkan/memperoleh kembali kasus yang paling menyerupai/relevan (similar) dengan kasus yang baru. Tahap retrieval ini dimulai dengan menggambarkan/ menguraikan sebagian masalah, dan diakhiri jika ditemukannya kecocokan terhadap masalah sebelumnya yang tingkat kecocokannya paling tinggi. Bagian ini mengacupada segi identifikasi, kecocokan awal, pencarian dan pemilihan serta eksekusi.

\section{Reuse}

Memodelkan/menggunakan kembali pengetahuan dan informasi kasus lama berdasarkan bobot kemiripan yang paling relevan ke dalam kasus yang baru, sehingga menghasilkan usulan solusi dimana mungkin 
diperlukan suatu adaptasi dengan masalah yang baru tersebut.

\section{Revise}

Meninjau kembali solusi yang diusulkan kemudian mengetesnya pada kasus nyata (simulasi) dan jika diperlukan memperbaiki solusi tersebut agar cocok dengan kasus yang baru.

\section{Retain}

Mengintegrasikan/menyimpan kasus baru yang telah berhasil mendapatkan solusi agar dapat digunakan oleh kasus-kasus selanjutnya yang mirip dengan kasus tersebut. Tetapi Jika solusi baru tersebut gagal, maka menjelaskan kegagalannya, memperbaiki solusi yang digunakan, dan mengujinya lagi. Yang melibatkan sejumlah langkah-langkah spesifik, yang akan dijelaskan pada gambar 2.3 dan gambar 2.4 berikut ini :

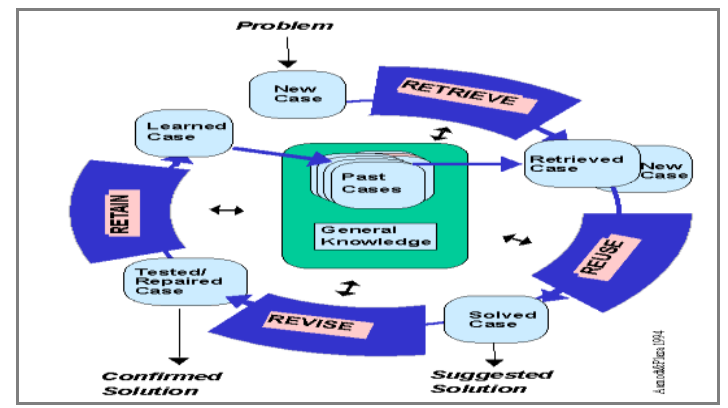

Gambar 2 Metode Case-Based Reasoning

Untuk menghitung kemiripan kasus, digunakan rumus berikut :

Total Similarity $=$

$$
\frac{\sum_{I=1}^{N} W i \cdot \operatorname{Sim}\left(f i^{T}{ }_{0} f i^{S}\right)}{\sum_{i=1}^{N} W i} \ldots \ldots \ldots
$$

Keterangan :

$\mathrm{T}$ : kasus baru

$\mathrm{S}$ :kasus yang ada dalam penyimpan

$\mathrm{n}$ : jumlah atribut dalam masing-masing kasus

i: atribut individu antara $1 \mathrm{~s} / \mathrm{d} \mathrm{n}$

f: fungsi similarityantara kasus $\mathrm{T}$ dan kasus $\mathrm{S}$

Wi:bobot yang diberikan kepada atribut ke -i

\section{METODE PENELITIAN}

\subsection{Analisis dan Perancangan}

Sistem pakar diagnosa penyakit pada tanaman cabai dapat digunakan oleh petani dalam mendiagnosa penyakit yang menyerang tanaman cabai berdasarkan kaidah mesin inferensi Case Based Reasoning (CBR). Para pengguna seperti petani dapat mengoperasikan aplikasi ini dengan menjawab pertanyaanpertanyaan yang diajukan oleh sistem. Apabila pertanyaan sesuai dengan basis pengetahuan maka sistem akan memberikan informasi penyakit dan solusi penanganan penyakit tersebut dari suatu sistem sangat di perlukan untuk mengetahui kegiatan-kegiatan yang sedang berjalan dalam suatu system. Tujuan mengetahui kegiatan-kegiatan tersebut adalah untuk memahami dan mengerti jalanan nya sistem serta hambatan-hambatan yang terdapat dalam sistem pakar penerapan metode case based reasoning untuk identifikasi penyakit cabai berbasis web tersebut. Pada tahap ini yang perlu dilakukan adalah analisis terhadap sistem yang sedang berjalan dan bagaimana alur program yang sedang berjalan yang akan di gambarkan dalam bentuk analisis kebutuhan fungsional, analisis kebutuhan non-fungsioanal dan analisis pengguna.

\subsection{Analisis Kebutuhan Sistem}

Dalam perancangan sebuah sistem/aplikasi dibutuhkan adanya analisis guna mendapatkan data-data yang akan dibutuhkan sistem dalam melakukan perancangan. Analisis sistem berupa analisis sistem baru, analisis kebutuhan perangkat keras, kebutuhan perangakat lunak dan analisis kebutuhan informasi.

\subsubsection{Analisis Sistem}

Dengan adanya sistem pakar untuk mendiagnosa penyakit pada tanaman cabai diharapkan dapat membantu para petani tanaman cabai dalam mendiagnosa penyakit. Diagnosa penyakit dilakukan ketika tanaman mengalami gejala-gejala berdasarkan basis pengetahuan gejala-gejala penyakit tanaman cabai yang terdapat pada sistem. Petani yang melakukan diagnosa berdasarkan gejala-gejala yang muncul akan diproses oleh aplikasi sistem pakar selanjutnya sistem akan memberikan informasi penyakit dan solusi penanganannya.

\subsubsection{Analisis Kebutuhan}

Kebutuhan informasi tidak terlepas dalam penelitian ini guna mendukung perancangan sistem yang sesuai dengan penerapan di lapangan. Informasi yang dibutuhkan antara lain seperti informasi mengenai penyakit-penyakit dan gejala serta solusi penangan terhadap penyakit tanaman cabai.

Informasi mengenai penyakit tanaman cabai diperlukan dalam pengenalan penyakit apa saja yang terdapat pada tanaman cabai. Gejala penyakit dibutuhkan untuk mendeteksi gejalagejala yang mungkin timbul ketika tanaman cabai menderita penyakit. Informasi mengenai solusi yaitu bagaimana mengambil solusi penanganan ketika penyakit pada tanaman cabai telah terdeteksi berdasarkan hasil diagnosa. 


\subsection{Data Flow Diagram (DFD) Level 0}

Perancangan sistem menguraikan bagaimana alur proses input maupun output dari sistem yang akan dihasilkan. Perancangan sistem ini dapat digambarkan melalui Dfd digunakan untuk menggambarkan keseluruhan dari sistem yang dirancang. Adapun perancangannya dapat dilihat pada gambar 4 berikut :

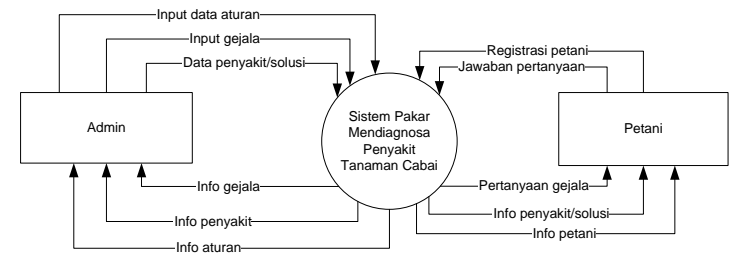

Gambar 3 DFD level 0 Sistem Pakar Penyakit Tanaman cabai

\subsection{Flowchart Sistem.}

Alur Bagan sistem (flowchart System) adalah bagan-bagan yang mempunyai arus dan menggambarkan langkah-langkah penyelesaian suatu masalah. Metode Case Based Reasoning (CBR) Similarity adalah pendekatan untuk mencari kasus dengan menghitung kedekatan antara kasus baru dengan kasus lama, yaitu berdasarkan pada pencocokan bobot dari sejumlah fitur yang ada. Adapun flowchart yang dibuat untuk menggambarkan alur dari aplikasi ini adalah sebagai berikut :

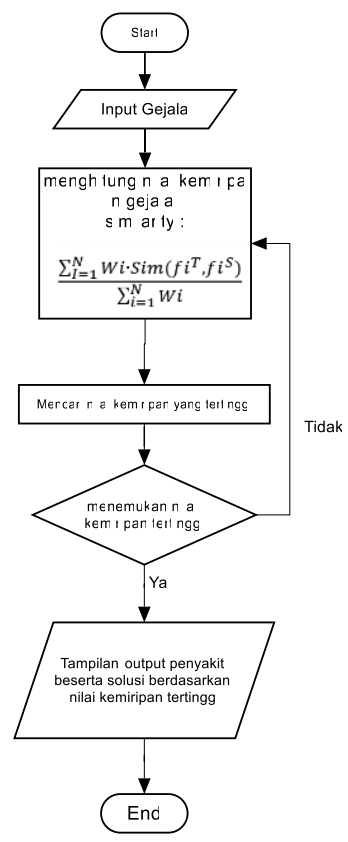

Gambar 5 Flowchat alur metode case based reasoning

\section{HASIL DAN PEMBAHASAN}

\subsection{Halaman Login}

Form login administrator digunakan untuk melakukan login bagi administrator untuk masuk ke halaman utama admin. Tampilan form login admin seperti pada gambar 6 berikut :

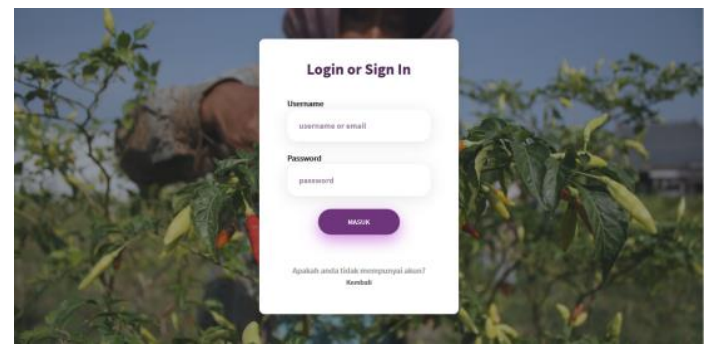

Gambar 6 Form Login Admin

\subsection{Halaman Utama Administrator}

Halaman utama administrator merupakan halaman utama pada bagian admin untuk melakukan semua kegiatan dalam sistem. Tampilannya seperti pada gambar 7 berikut :

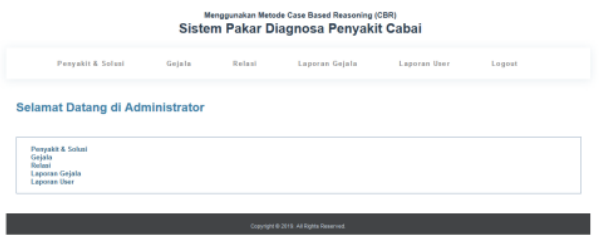

Gambar 7 Halaman Utama Administrator

\subsection{Halaman Data Penyakit}

Halaman data penyakit digunakan untuk menginputkan dan menampilkan data penyakit. Tampilannya seperti pada gambar 7 berikut :

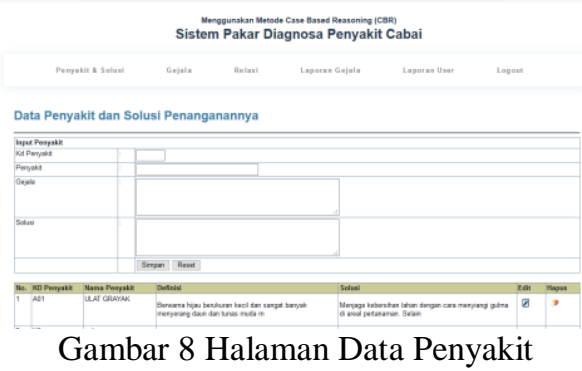

\subsection{Form Input Data Gejala}

Form data gejala digunakan untuk menginputkan dan menampilkan data gejala. Tampilannya seperti pada gambar 9 berikut : 


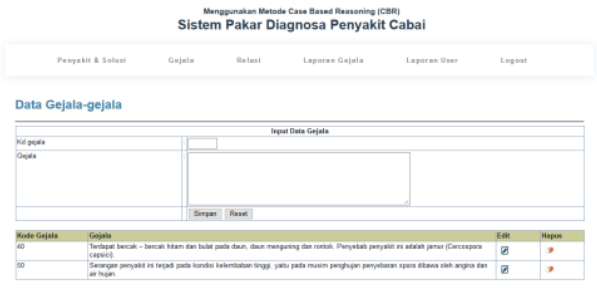

Gambar 9 Form Input Data Gejala

\subsection{Form Input Data Relasi}

Form input data relasi digunakan untuk mengatur relasi antar penyakit dan gejala. Adapun tampilannya dapat dilihat pada gambar 10 berikut :

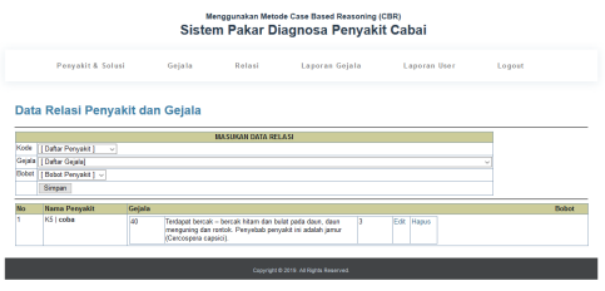

Gambar 10 Form Input Data Relasi

\subsection{Form Laporan Gejala}

Laporan data gejala digunakan untuk menampilkan data-data gejala dalam sistem. Tampilannya seperti pada gambar 11 berikut :

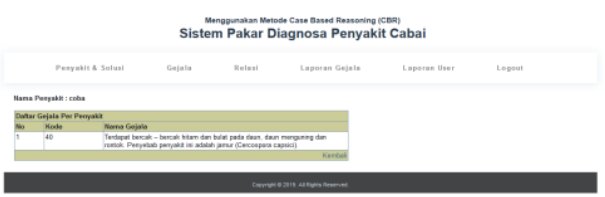

Gambar 11 Form Laporan Gejala

\subsection{Form Laporan User}

Form laporan user digunakan untuk menampung data pengguna sistem web. Adapun tampilannya dapat dilihat pada gambar 12 berikut :

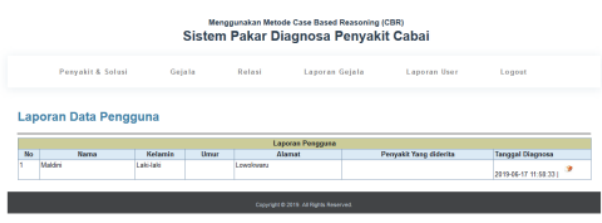

Gambar 12 Halaman Laporan Pengguna

\subsection{Form Regisrasi Pengguna}

Form registrasi pengguna digunakan untuk melakukan registrasi bagi pengguna aplikasi. Tampilannya dapat dilihat pada gambar 13 berikut :

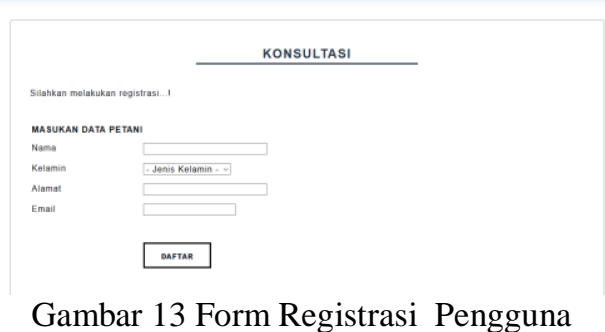

\subsection{Halaman Utama Aplikasi}

Halaman utama merupakan halaman yang pertama tampil ketika diakses oleh user/ pengguna sehingga tidak perlu melakukan Login terlebih dahulu. Halaman ini menunjukan informasi jenis penyakit cabai dan gejala- gejala cabai. tampilan dapat dilihat pada Gambar 14 dibawah ini

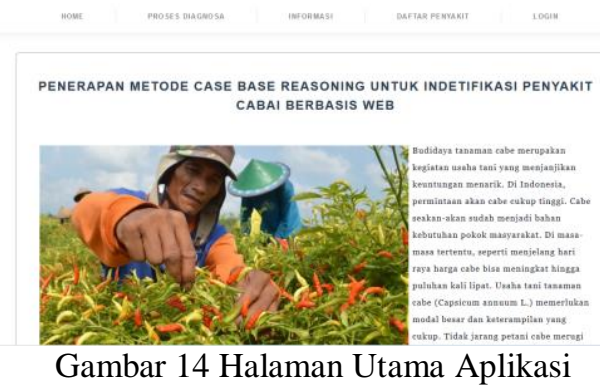

\subsection{Form Diagnosa Penyakit}

Form diagnosa penyakit digunakan untuk memilih penyakit yang terjadi pada cabai. Tampilannya dapat dilihat pada gambar 15 berikut :

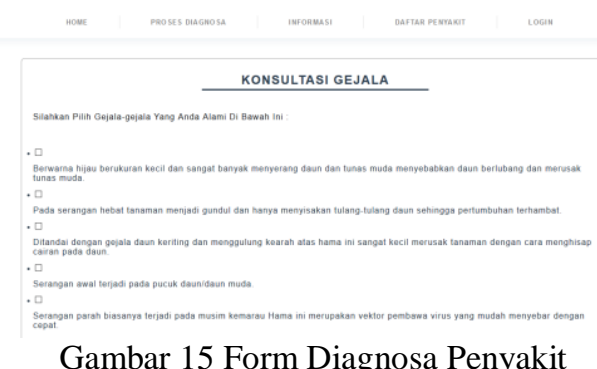

\subsection{Halaman Hasil Proses Diagnosa}

Halaman hasil digunakan untuk menampilkan hasil dari proses diagnosa penyakit. Tampilaannya dapat dilihat seperti gambar 16 berikut : 


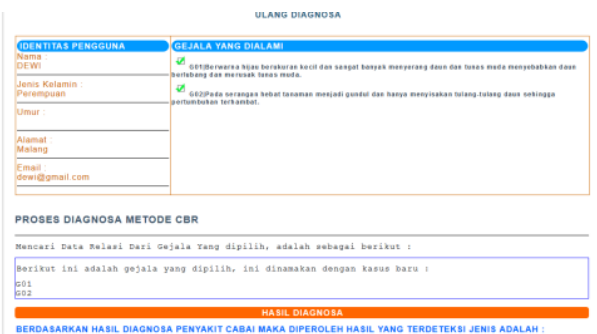

Gambar 16 Halaman Hasil Proses Diagnosa

\subsection{Implementasi Metode Case Based Reasoning}

Pada pengujian metode ini dilakukan dengan perhitungan manual, pada pengujian ini dilakukan untuk membandingan antara perhitungan manual dengan perhitungan sistem.

\section{Pendataan Alternatif Dari Data Gejala}

Pada penentuan alternatif yaitu menggunakan data yang sudah dinputkan kedalam database terdapat 5 data yang akan diproses.seperti yang ditunjukkan pada Tabel 1 .

Tabel 1 Tabel Alternatif

\begin{tabular}{|c|c|}
\hline \multicolumn{2}{|c|}{ Kriteria } \\
\hline Petani & Gejala Dipilih \\
\hline \multirow{2}{*}{ ABU } & 60 \\
\cline { 2 - 3 } & 15 \\
\hline
\end{tabular}

\section{Melihat Kasus Lama}

Melihat kasus lama dalam database yang nantinya akan dijadikan sebagai perbandingan. Terdapat 5 data lama yang dibandingkan pada kasus ini. Seperti yang ditunjukkan pada Tabel 2.

Tabel 4.2 Tabel Data Lama

\begin{tabular}{|c|l|c|c|}
\hline No & Petani & Penyakit & Gejala \\
\hline 1 & ANI & Ulat Grayak & $60,15,50$ \\
\hline 2 & UMAR & Thrips & $15,25,70$ \\
\hline 3 & NAWI & Tungau & $50,15,100$ \\
\hline 4 & DOEL & Kutu Daun & $25,50,50$ \\
\hline 5 & SWASTIKA & Bercak Daun & $15,15,100$ \\
\hline
\end{tabular}

\section{Perbandingan Antar kasus}

Setelah melihat kasus lama dalam database dilakukanlah perbandingan pada setiap kasus. Seperti yang ditunjukkan pada perhitungan berikut ini.

\begin{tabular}{|l|l|}
\hline \multicolumn{2}{|c|}{ Kasus 1 } \\
\hline Data Lama \\
\hline Nama & \multicolumn{1}{l|}{ Ani } \\
\hline Gejala & $60,15,50$ \\
\hline \multicolumn{1}{|c|}{ Kasus 2 } \\
\hline Data Lama \\
\hline Nama & Umar \\
\hline Gejala & $15,25,70$ \\
\hline Kasus 3 \\
\hline Data Lama \\
\hline Nama & Nawi \\
\hline Gejala & $50,15,100$ \\
\hline Kasus 4 \\
\hline Data Lama \\
\hline Nama & Doel \\
\hline Gejala & $25,50,50$ \\
\hline Kasus 5 \\
\hline Data Lama & Swastika \\
\hline Nama & $15,15,100$ \\
\hline Gejala \\
\hline
\end{tabular}

\begin{tabular}{|l|l|}
\hline Data Baru & \\
\hline Nama & Abu \\
\hline Gejala & 60,15 \\
\hline
\end{tabular}

\section{Perhitungan Similarity}

Dari hasil perhitungan similarity antara pasien Abu dengan Ani, Umar, Nawi, Doel dan Swastika seperti dibawah ini

$$
\begin{aligned}
& \text { Simillarity } I=\frac{(60 \times 1)+(15 \times 0)+(60 \times 0)+(15 \times 1)+(60 \times 0)+(15 \times 0)}{100}=\frac{75}{100}=0,75 \\
& \text { Simillarity } 22=\frac{(60 \times 0)+(15 \times 1)+(60 \times 0)+(15 \times 0)+(60 \times 0)+(15 \times 0)}{100}=\frac{15}{100}=0,15 \\
& \text { Simillarity } 33=\frac{(60 \times 0)+(15 \times 0)+(60 \times 0)+(15 \times 0)+(60 \times 0)+(15 \times 0)}{100}=\frac{0}{100}=0 \\
& \text { Simillarity } D 4=\frac{(60 \times 0)+(15 \times 0)+(60 \times 0)+(15 \times 0)+(60 \times 0)+(15 \times 0)}{100}=\frac{0}{100}=0 \\
& \text { Simillarity } 55=\frac{(60 \times 0)+(15 \times 1)+(60 \times 0)+(15 \times 0)+(60 \times 0)+(15 \times 0)}{100}=\frac{15}{100}=0,15
\end{aligned}
$$

Gambar 17 perhitungan similarity antara pasien

\section{Hasil Perhitungan}

Setelah dilakukan perhitungan dan mendapatkan nilai similiarity data akan dirankingkan seperti yang ditunjukkan pada Tabel 3

\begin{tabular}{|l|c|c|}
\hline \multicolumn{3}{|c|}{ Ranking } \\
\hline Kasus 1 & 0.75 & 1 \\
\hline Kasus 2 & 0.15 & 2 \\
\hline Kasus 3 & 0 & 4 \\
\hline Kasus 4 & 0 & 5 \\
\hline Kasus 5 & 0,15 & 3 \\
\hline
\end{tabular}




\section{Kesimpulan}

Hasil perhitungan dari metode Case Based Reasoning dengan menggunakan teknik pembobotan similiarity, maka terdapat 5 kasus lama yang dibandingkan dengan kasus baru, yaitu Ani, Umar, Nawi, Doel dan Swastika namun masing-masing memiliki persamaan yang berbeda. didapatkan nilai kesamaan yang terbesar yaitu kasus dengan Ani sebanyak 0,75 dan disusul oleh Umar dan swastika dengan nilai 0,15 serta yang terakhir Nawi dan Doel dengan perolehan similiarity sama dengan 0 . Untuk tampilan dari perhitungan aplikasi dapat dilihat pada Gambar 18

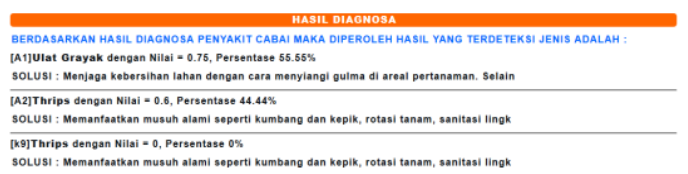

Gambar 18 perhitungan similarity antara pasien menggunakan website

\subsection{Pengujian Fungsional Sistem}

Pengujian sistem merupakan proses menampilkan sistem dengan maksud untuk menemukan adanya kesalahan atau tidak pada sistem sebelum sistem dipublikasikan untuk digunakan oleh masyarakat. Hasil pengujian sistem

\subsection{Kuisioner Pengujian user}

Pengujian pengguna terhadap system pakar penerapan metode case based reasoning untuk identifikasi penyakit cabai berbasis website ini dilakukan dengan memberikan beberapa pertanyaan kepada pengguna yang didasarkan atas pengujian sistem aplikasi. Pengujian pengguna ini dilakukan kepada 10 orang responden untuk memberikan penilaian terhadap aplikasi ini. Adapun hasil dari pengujian pengguna ini ditunjukkan pada tabel 8 seperti berikut :

Tabel 8 Pengujian User

\begin{tabular}{|c|c|}
\hline No & Pertanyaan \\
\hline 1. & $\begin{array}{l}\text { Sejauh mana aplikasi ini membantu saudara } \\
\text { dalam proses pemilihan gejala dan hasil } \\
\text { diagnosa mudah dipahami? } \\
\text { A. Sangat Membantu } \\
\text { B. Membantu } \\
\text { C. Cukup Membantu } \\
\text { D. Tidak Membantu }\end{array}$ \\
\hline 2. & $\begin{array}{l}\text { Apakah Aplikasi ini cukup mudah untuk di } \\
\text { gunakan? } \\
\text { A. Sangat Mudah } \\
\text { B. Mudah } \\
\text { C. Cukup Mudah } \\
\text { D. Sulit }\end{array}$ \\
\hline
\end{tabular}

\begin{tabular}{|c|c|}
\hline 3. & $\begin{array}{l}\text { Apakah hasil yang ditampilkan pada aplikasi } \\
\text { sesuai dengan kebutuhan/keinginan anda? } \\
\text { A. Sangat Sesuai } \\
\text { B. Sesuai } \\
\text { C. Cukup Sesuai } \\
\text { D. Tidak Sesuai }\end{array}$ \\
\hline 4. & $\begin{array}{l}\text { Bagaimana pendapat anda mengenai tampilan } \\
\text { desain dan warna pada aplikasi ini? } \\
\text { A.Tampilan Secara Keseluruhan sangat Baik } \\
\text { B. Desain Dari Sistem Sangat Baik, Tetapi } \\
\text { Warnanya Kurang Tepat } \\
\text { C. Desain Sistem Cukup Baik } \\
\text { D. Tampilan Dan Warna Kurang } \\
\end{array}$ \\
\hline 5. & $\begin{array}{l}\text { Apakah tampilan hasil penyakit pada sistem } \\
\text { sudah sesuai dengan keilmuan pakar mengenai } \\
\text { penyakit cabai ? } \\
\text { A. Sangat Sesuai } \\
\text { B. Sesuai } \\
\text { C. Cukup Sesuai } \\
\text { D. Tidak Sesuai }\end{array}$ \\
\hline 6. & $\begin{array}{l}\text { Bagaimana pendapat anda mengenai tampilan } \\
\text { diagnosa pada aplikasi ini? } \\
\text { A. Amat Baik } \\
\text { B. Baik } \\
\text { C. Cukup Baik } \\
\text { D. Sedang }\end{array}$ \\
\hline 7. & $\begin{array}{l}\text { Bagaimana pendapat anda tentang keseluruhan } \\
\text { dari aplikasi ini ? } \\
\text { A. Amat Baik } \\
\text { B. Baik } \\
\text { C. Cukup Baik } \\
\text { D. Sedang }\end{array}$ \\
\hline
\end{tabular}

\section{Jawaban Kuisioner Keterangan :}

Hasil dari pengujian user yang talah disampaikan, yaitu terdapat 10 responden yang ditunjukkan pada Tabel 4.6, Maka presentase penilaian terhadap penelitian analisis metode Case Based Reasoning penyakit cabai berbasis web disimpulkan bahwa.

$$
\begin{array}{ll}
\text { Sangat Setuju } & =(13 / 100) * 100 \%=13 \% \\
\text { Setuju } & =(26 / 100) * 75 \%=19,5 \% \\
\text { Cukup Setuju } & =(26 / 100) * 50 \%=19,5 \% \\
\text { Tidak Setuju } & =(5 / 100) * 25 \%=1,25 \%
\end{array}
$$

Maka dapat disimpulkan bahwa dari hasil pengujian kepada 11 responden menggunakan kuisioner terdapat $13 \%$ yang menyatakan sangat setuju, 19,5\% setuju, 19,5\% Cukup setuju, dan $1,25 \%$ tidak setuju dengan adanya aplikasi ini dalam membantu proses penentuan yang diharapkan. 


\section{KESIMPULAN DAN SARAN}

\subsection{Kesimpulan}

Berdasarkan hasil penelitian yang telah dilakukan, dapat ditarik kesimpulan bahwa:

1. Telah berhasil dibangun aplikasi "Sistem Pakar Cabai" untuk membantu masyarakat umum dan petani dalam mengidentifikasi penyakit yang disebabkan berdasarkan gejalagejala yang diberikan.

2. Sistem pakar yang dibangun dapat bermanfaat bagi masyarakat umum dan petani untuk mengetahui informasi tentang penyakit cabai.

3. Hasil pengujian fungsional menunjukkan bahwa sistem pakar yang dibangun telah berjalan sesuai yang diharapkan.

\subsection{Saran}

Beberapa saran untuk pengembangan lebih lanjut yang dapat diberikan setelah dilakukannya penelitian ini adalah sebagai berikut:

1. Penambahan data penyakit cabai yang lebih lengkap.

2. Penyempurnaan desain user interface aplikasi.

3. Penyederhanaan bahasa pada gejala dan penyakit cabai agar mudah dimengerti.

\section{DAFTAR PUSTAKA}

[1] Kartikasari, M., Santoso, P.B. and Yudaningtyas, E., 2016. Penerapan Case Based Reasoning pada Sistem Pendukung Keputusan Penanganan Komplain Penyewa Mall (Studi Kasus: Maspion Square Mall, Surabaya). Jurnal EECCIS, 9(2), pp.138143.

[2] Sari, H.L., 2012. SISTEM PAKAR KEHILANGAN PASOKAN LISTRIK PADA PT PLN (PERSERO) MENGGUNAKAN METODE INFERENSI BACKWARD CHAINING. JURNAL MEDIA INFOTAMA, 8(1).

[3] Ungkawa, U., Rosmala, D. and Aryanti, F., 2013. Pembangunan Aplikasi Travel Recommender Dengan Metode Case Base Reasoning. Jurnal, Jurusan Teknik Informatika, Institut Teknologi Nasional, Bandung.

[4] Nurfalach, D.R., 2010. Budidaya tanaman cabai merah (Capsicum annum L.) Di UPTD perbibitan tanaman hortikultura Desa Pakopen Kecamatan Bandungan Kabupaten semarang (Doctoral dissertation, Universitas Sebelas Maret). 